\title{
Pengaruh brand image, persepsi harga dan kualitas layanan terhadap minat beli ulang pada Lazada
}

\author{
$1^{*}$ Arini Nur Safitri \\ ${ }^{1}$ Universitas Sarjanawiyata Tamansiswa, Jalan Kusumanegara Yogyakarta 55165 \\ *e-mail korespondensi: arininursafiri603@yahoo.com
}

\begin{tabular}{|c|c|}
\hline Article Info & Abstract \\
\hline $\begin{array}{l}\text { Keywords: } \\
\text { Brand image, Price } \\
\text { perception, Service } \\
\text { quality, Repurchase } \\
\text { interest }\end{array}$ & $\begin{array}{l}\text { This study aims to examine the effect of brand image, perceived price, and service } \\
\text { quality on repurchasing interest in lazada. Respondents in this study were Lazada } \\
\text { users in the students of the Faculty of Economics, Sarjanawiyata Tamansiswa } \\
\text { University in Yogyakarta. The analysis instruments in this study were data quality } \\
\text { test, classical assumption, multiple linear regression, t test, F test, and coefficient of } \\
\text { determination. This study shows that brand image has a positive and significant } \\
\text { influence on repurchase interest, and service quality has a significant positive effect } \\
\text { on repurchase interest. Other results from this study indicate that the perception of } \\
\text { prices has a negative influence on repurchasing interest. }\end{array}$ \\
\hline Info Artikel & Abstrak \\
\hline $\begin{array}{l}\text { Kata Kunci: } \\
\text { Citra merek, } \\
\text { Persepsi harga, } \\
\text { Kualitas layanan, } \\
\text { Minat membeli } \\
\text { kembali }\end{array}$ & $\begin{array}{l}\text { Penelitian ini bertujuan untuk menguji pengaruh citra merek, persepsi harga, dan } \\
\text { kualitas layanan terhadap minat beli kembali di lazada. Responden dalam penelitian } \\
\text { ini adalah pengguna Lazada pada mahasiswa Fakultas Ekonomi Universitas } \\
\text { Sarjanawiyata Tamansiswa Yogyakarta. Instrumen analisis dalam penelitian ini } \\
\text { adalah uji kualitas data, asumsi klasik, regresi linier berganda, uji t, uji F, dan } \\
\text { koefisien determinasi. Penelitian ini menunjukkan bahwa citra merek berpengaruh } \\
\text { positif dan signifikan terhadap minat beli kembali, dan kualitas layanan berpengaruh } \\
\text { positif signifikan terhadap minat beli kembali. Hasil lain dari penelitian ini } \\
\text { menunjukkan bahwa persepsi harga berpengaruh negatif terhadap minat beli } \\
\text { kembali. }\end{array}$ \\
\hline
\end{tabular}

\section{PENDAHULUAN}

Perkembangan teknologi komunikasi dan internet yang semakin pesat di era globalisasi ini mendorong terjadinya perubahan kultur dalam kehidupan manusia. Saat ini media elektronik menjadi salah satu media yang yang sangat diandalkan untuk melakukan komunikasi maupun bisnis. Media internet selain digunakan untuk media internet juga digunakan untuk media informasi, internet juga digunakan sebagai proses pembelian dan penjualan produk, jasa, dan informasi secara online yang tersedia e-commerce. 


\section{Entrepreneurship Bisnis Manajemen Akuntansi (E-BISMA), 1(1), 1-9 \\ Arini Nur Safitri}

Salah satu e-commerce yang mulai berkembang pesat di indonesia adalah situs jual beli online. Situs jual beli di indonesia sebenarnya sudah lama bermunculan, namun belakanggan ini situs jual beli online semakin marak. Banyak orang yang tertarik untuk melakukan jual beli secara online di situs jual beli online. Melalui situs jual beli ini, pengusaha dapat menjangkau target market yang jauh lebih luas dengan biaya yang lebih murah. Salah satu jual beli online adalah Lazada yang diluncurkan pada bulan Maret 2012 dan berkembang pesat hingga saat ini. Lazada merupakan salah satu bagian dari jaringan retail online.

Lazada merupakan perusahaan yang bergerak di bidang layanan jual beli online dan ritel e-commerce, hasil pengembangan dari perusahaan inkubator teknologi internet asal Jerman yaitu Rocket Internet. Lazada berharap dapat memberikan kemudahan bagi masyarakat dalam membeli berbagai jenis produk dari berbagai kategori, mulai dari produk elektronik, dekorasi rumah, produk kesehatan hingga kecantikan dengan cukup mengakses situs maupun aplikasi dari Lazada.

Menurut Bilgin (2018) brand image yang baik adalah memberikan kualitas produk yang baik bagi konsumen. Merek yang berhasil memiliki potensi yang besar untuk menghasilkan keuntungan lebih banyak lagi bagi perusahaan mampu memanfaatkan merek tersebut secara agresif dan terus menurus melalui berbagai cara seperti peluasaan merek atau peluasaan lini. Penilaian konsumen tentang sebuah produk tidak hanya dilihat dari faktor brand image saja, tetapi sikap konsumen terhadap produk juga berperan penting dalam keputusan terhadap minat beli ulang.

Menurut Zulkarnaen \& Amin (2018) strategi penentuan harga (pricing) sangat signifikan dalam pemberian value kepada konsumen dan mempengaruhi image produk, serta keputusan konsumen untuk membeli. Pricing juga berhubungan dengan pendapatan dan turut mempengaruhi supply atau marketing channels. Akan tetapi, yang paling penting adalah keputusan dalam princing harus konsisten dengan strategi pemasaran secara keseluruhan. Faktor lainnya yang dapat menentukan minat beli ulang adalah kualitas layanan. Penelitian yang dilakukan oleh Hana (2019), telah menunjukkan bahwa kualitas layanan merupakan faktor kunci keberhasilan pada pembelian secara online.

Minat pembelian ulang menunjukkan bahwa keinginan pelanggan untuk melakukan pembelian ulang untuk waktu yang akan datang, perilaku pembelian ulang seringkali dihubungkan dengan kepercayaan konsumen. Akan tetapi, pembelian ulang dapat dihubungkan juga dengan pembelian ulang yang akan dilakukan oleh konsumen di tempat tertentu yang disebabkan oleh faktor tertentu.

Karena hal tersebut diatas, maka peneliti termotivasi untuk meneliti pengaruh brand image, persepsi harga, dan kualitas layanan terhadap minat beli ulang. Peneliti mencoba menganalisis apakah setiap variabel saling berpengaruh positif antara variabel $\mathrm{X}$ dan variabel Y. Dan untuk mengetahui apakah setiap variabel $\mathrm{X}$ berpengaruh signifikan terhadap variabel Y. 


\section{KAJIAN TEORI DAN HIPOTESIS}

\section{Brand Image}

Brand image merupakan representasi dari keseluruhan persepsi terhadap merek dan dibentuk dari informasi dan pengalaman masa lalu terhadap merek itu sendiri. Menurut Kotler et al. (2012) brand image adalah persepsi dan keyakinan yang dilakukan oleh konsumen, seperti tercemin dalam asosiasi yang terjadi dalam memori konsumen.

Menurut Lupiyoadi (2013), indikator yang digunakan untuk mengukur brand image adalah sebagai berikut:

1) Citra pembuat yaitu sekumpulan asosiasi yang membuat dipresepsikan konsumen terhadap perusahaan yang membuat suatu produk atau jasa.

2) Citra pemakai yaitu sekumpulan asosiasi yang dipresepsikan konsumen terhadap pemakai yang menggunakan barang atau jasa.

3) Citra produk yaitu sekumpulan asosiasi yang dipresepsikan konsumen terhadap suatu produk.

\section{Persepsi Harga}

Rangkuti (2009) menyatakan bahwa persepsi harga adalah biaya relatif yang harus konsumen keluarkan untuk memperoleh produk atau jasa yang ia inginkan.

Menurut Dharmestha \& Handoko (2008) indikator-indikator persepsi harga adalah :

1) Kesesuaian harga produk dengan kualitas produk

2) Perbandingan harga dengan harga produk lain dan sejenis

3) Kesesuaian harga produk dengan manfaat yang didapat

\section{Kualitas Layanan}

Layanan dapat didefinisikan sebagai segala bentuk kegiatan yang diberikan oleh satu pihak atau lebih kepada pihak lain yang memiliki hubungan dengan tujuan untuk dapat memberikan kepuasan kepada pihak kedua yang bersangkutan atas barang dan jasa yang diberikan.

Ada beberapa dimensi atau faktor yang digunakan konsumen atau pengguna jasa dalam menentukan kualitas layanan, menurut Tjiptono (2005) menyatakan bahwa ada lima dimensi pokok yang dapat digunakan untuk mengukur kualitas layanan, yaitu:

1) Bukti langsung (Tangibles)

2) Keandalan (Reliability)

3) Daya Tanggap (Responsiveness)

4) Jaminan (Assurance)

5) Empati (Emphaty)

\section{Minat Beli Ulang}

Minat beli ulang merupakan perilaku konsumen yang menunjukkan sejauh mana komitmennya untuk melakukan pembelian (Hadi, 2018). Kebutuhan dan keinginan konsumen akan barang atau jasa berkembang dari masa ke masa dan mempengaruhi perilaku 
mereka dalam pembelian produk. Menurut Ferdinand (2006) dan Arsyanti \& Astuti (2016) minat beli ulang dapat didefinisikan melalui indikator-indikator sebagai berikut:

1) Minat transaksional

2) Minat refrensial

3) Minat prefrensial

4) Minat eksploratif

\section{Pengaruh Brand Image terhadap Minat Beli Ulang}

Penelitian terdahulu yang dilakukan Fatmawati \& Soliha (2017), menyatakan Brand Image berpengaruh positif terhadap minat beli produk sepeda motor matic Honda. Berdasarkan penjelasan di atas, hipotesis dapat dirumuskan sebagai berikut

$\mathrm{H}_{1}$ : Brand image (BI) berpengaruh positif signifikansi terhadap minat beli ulang (MBU)

\section{Pengaruh Persepsi Harga terhadap Minat Beli Ulang}

Pada penelitian terdahulu yang dilakukan oleh Winahyu \& Soesanto (2012) yang meneliti tentang Analisis Pengaruh Persepsi harga, Kualitas Produk dan Daya Tarik Iklan Terhadap Minat Beli Air Minum Axogy menunjukkan bahwa Persepsi Harga tidak berpengaruh positif terhadap minat beli ulang. Berdasarkan uraian diatas, maka hipotesis yang diajukan dalam penelitian adalah.

$\mathrm{H}_{2}$ : Persepsi harga $(\mathrm{PH})$ berpengaruh positif signifikansi terhadap Minat Beli Ulang (MBU)

\section{Pengaruh Kualitas Layanan terhadap Minat Beli Ulang}

Penelitian mengenai kualitas dilakukan oleh Saidani et al (2019) dan Cahyono (2016) menunjukkan kualitas yang dirasakan dari keterlibatan produk dan kepuasan berpengaruh positif terhadap minat beli ulang, sedangkan nilai berpengaruh tidak langsung dengan minat beli ulang dan kepuasan. Berdasaran uraian dan penjelasan di atas, maka dapat diajukan hipotesis sebagai berikut:

$\mathrm{H}_{3}$ : Kualitas Layanan (KL) pengaruh positif signifikansi terhadap minat beli ulang (MBU)

\section{Pengaruh Brand Image, Persepsi Harga dan Kualitas Layanan terhadap Minat Beli Ulang}

Brand image merupakan identitas dari barang atau jasa. Sebuah merek yang terkenal dan terpecaya merupakan asset yang tidak ternilai. Harga yang standar dan mudah dijangkau oleh konsumen, serta konsumen akan mengetahui harga yang standar dan kualitas suatu produk yang baik merupakan harapan bagi setiap konsumen. Konsumen akan merasa senang jika harga yang dijanjikan oleh perusahan sesuai dengan yang diinginkan oleh konsumen, sehingga konsumen akan berminat untuk membeli produk tersebut. Dan dengan harga yang terjangkau dengan kualitas layanan yang baik akan menimbulkan kepuasan pelanggan serta meningkatkan kualitas layanan membentuk loyalitas pelanggan karena pelanggan merasa nyaman dan aman (Gofur, 2019). Sehingga pelanggan akan merasa senang dengan kualitas yang diberikan sehingga kosumen akan berminat untuk membeli produk lagi. 
$\mathrm{H}_{4}$ : Brand Image, Persepsi Harga dan Kualitas Layanan memiliki pengaruh positif signifikansi terhadap Minat Beli Ulang.

\section{METODE PENELITIAN}

Populasi dalam penelitian ini adalah pengguna Lazada yaitu Mahasiswa Fakultas Ekonomi Sarjanawiyata Tamansiswa di Yogyakarta. Sampel adalah bagian dari jumlah dan karakteristik yang dimiliki oleh populasi tersebut. Bila populasi besar dan penelitian tidak mungkin mempelajari semua yang ada pada populasi, misalnya keterbatasan dana, tenaga dan waktu maka penelitian dapat menggunakan sampel yang diambil dan populasi itu (Sugiyono, 2013). Jumlah sampel yang digunakan adalah 100 responden dengan mendasarkan penelitian sampel menurut Wulandari \& Iskandar (2018).

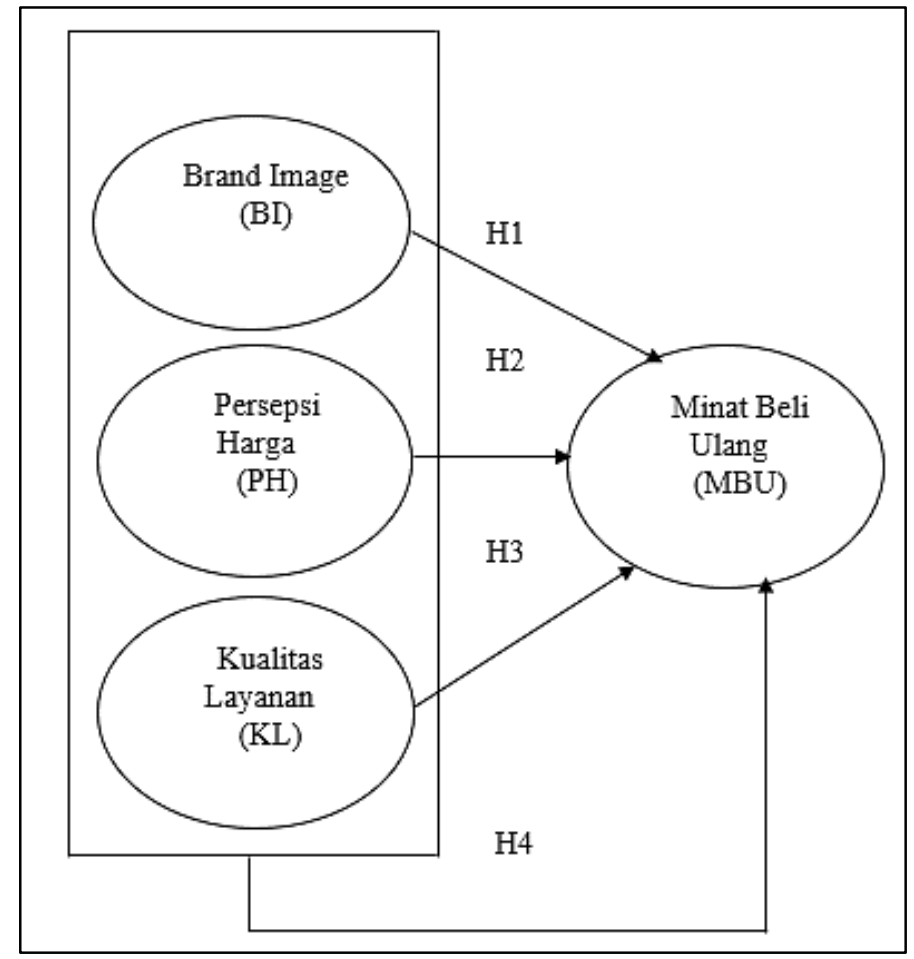

Gambar 1. Model Kerangka Pikir

Dalam penelitian ini menggunakan teknik probability sampling atau random sampling merupakan teknik sampling yang dilakukan dengan memberikan peluang atau kesempatan kepada seluruh anggota populasi untuk menjadi sampel. Pengambilan sampel dilakukan dengan menggunakan salah satu teknik yaitu accidental sampling. Data yang digunakan dalam penelitian ini adalah data primer Sumber data primer adalah sumber data penelitian yang diperoleh secara langsung yaitu dengan cara kuesioner/angket. dari uji reliabiltas dinyatakan suatu variabel dikatakan reliable jika memberikan nilai Cronbach Alpha > 0,70, hal ini sesuai dengan yang disampaikan (Ghozali, 2011). Berdasarkan pada hal tersebut, maka dapat disimpulkan bahwa semua variabel dalam penelitian ini dinyatakan reliabel atau andal, sehingga data yang diperoleh dapat dianalisis lebih lanjut. 


\section{Entrepreneurship Bisnis Manajemen Akuntansi (E-BISMA), 1(1), 1-9 \\ Arini Nur Safitri}

Pembahasan karakteristik responden ditunjukkan untuk mengetahui deskripsi mengenai profil responden dalam penelitian ini. Responden dalam ini adalah mahasiswa fakultas ekonomi universitas sarjanawiyata tamansiswa sebanyak 100 responden yang pernah melakukan minat beli ulang pada Lazada. Gambaran mengenai profil responden dalam penelitian ini terdiri dari jenis kelamin, usia responden, prodi. Hasil persentase berdasarkan jenis kelamin menunjukkan bahwa mayoritas responden adalah wanita. Hasil persentase responden berdasarkan usia menunjukkan bahwa mayoritas responden menunjukkan 21-25 tahun. Hasil persentase berdasarkan prodi menunjukkan bahwa mayoritas responden pengguna lazada mayoritas dari prodi manajemen sebesar $57 \%$.

Analisis regresi ganda digunakan apabila peneliti ingin meramal bagaimana keadaan (naik turunnya) variabel dependen, analisis regresi ganda ini digunakan apabila jumlah variabel independennya minimal 2 (Sugiyono, 2013). Uji asumsi klasik atau uji prasyarat dibutuhkan jika penelitian menggunakan metode parametik. Uji asumsi klasik meliputi : Uji Normalitas, Uji Multikolinearitas dan Uji Heterokedastisitas.

Persamaan regresi untuk penelitian ini sebagi berikut :

$\mathrm{MBU}=\mathrm{b} 1 \mathrm{BI}+\mathrm{b} 2 \mathrm{PH}+\mathrm{b} 3 \mathrm{KL}$

Keterangan. MBU: Minat Beli Ulang

BI: Brand Image, PH:Persepsi Harga, KL: Kualitas Layanan

Uji t digunakan untuk mengetahui apakah secara parsial variabel independen/bebas berpengaruh terhadap variabel dependen/terikat, dengan asumsi variabel independen lainnya kostan. Dasar pengambilan keputusan adalah: $\mathrm{H}_{\mathrm{o}}$ ditolak atau $\mathrm{H}_{\mathrm{a}}$ diterima jika nilai signifikan $\mathrm{t}$ atau $\mathrm{p}$ value $<5 \%$. Dan untuk Uji $\mathrm{F}$ Untuk mengetahui pengaruh variabel independen terhadap variabel dependen secara simultan atau untuk menguji keberartian koefisien regresi secara keseluruhan. Koefisien Determinan $\mathrm{R}^{2}$ intinya digunakan untuk mengukur seberapa jauh kemampuan model dalam menerangkan variasi variabel dependen (Ghozali, 2011), nilai koefisien determinasi adalah antara nol atau satu, apabila $\mathrm{R}^{2}$ kecil maka kemampuan variabel-variabel independen dalam menjelaskan variabel-variabel dependen terbatas dan apabila nilai $\mathrm{R}^{2}$ mendekati satu maka variabel independen hampir semua informasi yang dibutuhkan untuk memprediksi variasi variabel dependen

\section{HASIL DAN PEMBAHASAN}

Hasil pengujian hipotesis pertama $\left(\mathrm{H}_{1}\right)$ yang dilakukan, ditemukan bahwa brand image berpengaruh positif dan signifikan terhadap minat beli ulang, hal ini ditunjukkan dengan nilai t-hitung lebih besar dari pada t-tabel $(2,961>1,98498)$ dengan probabilitas $(0,004)$ lebih kecil dari taraf signifikan 0,05, dengan demikian $\mathrm{H}_{\mathrm{o}}$ ditolak dan $\mathrm{H}_{\mathrm{a}}$ diterima, artinya variabel brand image mempunyai pengaruh positif dan signifikan terhadap minat beli ulang (Hidayah \& Apriliani, 2019).

Hasil pengujian hipotesis kedua $\left(\mathrm{H}_{2}\right)$ yang dilakukan, ditemukan bahwa persepsi harga tidak berpengaruh terhadap minat beli ulang, hal ini ditunjukkan dengan t-hitung lebih kecil dari t-tabel $(1,627<1,98498)$ dengan probabilitas $(0,107)$ lebih besar dari taraf signifikan 0,05 , dengan demikian $\mathrm{H}_{\mathrm{o}}$ diterima dan $\mathrm{H}_{\mathrm{a}}$ ditolak, artinya variabel persepsi harga tidak mempunyai pengaruh positif dan signifikan terhadap minat beli ulang (Nisa, 2018). Hasil 


\section{Entrepreneurship Bisnis Manajemen Akuntansi (E-BISMA), 1(1), 1-9 \\ Arini Nur Safitri}

pengujian hipotesis ketiga $\left(\mathrm{H}_{3}\right)$ yang dilakukan, ditemukan bahwa kualitas layanan berpengaruh terhadap minat beli ulang. hal ini ditunjukkan dengan t-hitung lebih besar dari t-tabel $(2,847>1,98498)$ dengan probabilitas $(0.005)$ lebih kecil dari taraf signifikan 0,05 , dengan demikian $\mathrm{H}_{\mathrm{o}}$ ditolak dan $\mathrm{H}_{\mathrm{a}}$ diterima, artinya variabel kualitas layanan mempunyai pengaruh positif dan signifikan terhadap minat beli ulang (Ramadhan \& Santosa, 2017).

Brand image, persepsi harga, dan kualitas layanan berpengaruh secara simultan terhadap minat beli ulang. Hal ini ditunjukkan dengan nilai F-hitung adalah 44,412. Dengan nilai signifikan sebesar 0,000, dan nilai F-tabel adalah 2,70. Dengan demikian dapat disimpulakan bahwa F-hitung $>$ F-tabel dengan tingkat signifikan $0,000<0,05(\mathrm{p}<0,05)$.

\section{KESIMPULAN DAN SARAN}

Berdasarkan hasil penelitian dan pembahasan tentang pengaruh brand image, persepsi harga, kualitas layanan terhadap minat beli ulang pada lazada pada mahasiswa Fakultas Ekonomi Universitas Sarjanawiyata Tamansiswa di Yogyakarta. Maka dapat diambil beberapa kesimpulan sebagai berikut:

Hasil penelitian diperoleh persamaan regresi sebagai berikut:

$\mathrm{MBU}=0,374 \mathrm{BI}+0,178 \mathrm{PH}+0,284 \mathrm{KL}$. Berdasarkan hasil Uji T, brand image memiliki pengaruh positif dan signifikan terhadap minat beli ulang dengan nilai t-hitung lebih besar dari pada t-tabel $(2,961>1,98498)$ dengan probabilitas $(0,004)$ lebih kecil dari taraf signifikan 0,05 . Adanya pengaruh ini menunjukkan semakin positif brand image terhadap konsumen Lazada, maka akan semakin meningkatkan minat beli ulang konsumen terhadap produk yang ada di Lazada.

Persepsi harga tidak pengaruh positif dan signifikan terhadap minat beli ulang dengan nilai t-hitung lebih kecil dari pada t-tabel $(1,627>1,98498)$ dengan probabilitas $(0,107)$ lebih besar dari taraf signifikan 0,05. Adanya pengaruh ini menunjukkan semakin tidak berpengaruh positif persepsi harga terhadap konsumen Lazada, maka akan semakin menurunnya minat beli ulang konsumen terhadap produk yang ada di Lazada.

Kualitas layanan memiliki pengaruh positif dan signifikan terhadap minat beli ulang dengan nilai t-hitung lebih besar dari pada t-tabel $(2,847>1,98498)$ dengan probabilitas $(0,005)$ lebih kecil dari taraf signifikan 0,05 . Adanya pengaruh ini menunjukkan semakin positif kualitas layanan terhadap konsumen Lazada, maka akan semakin meningkatkan minat beli ulang konsumen terhadap produk yang ada di Lazada.

Brand image, persepsi harga, dan kualitas layanan berpengaruh secara simultan terhadap minat beli ulang dengan nilai F-hitung adalah 44,412. Dengan nilai signifikan sebesar 0,000, dan nilai F-tabel adalah 2,70. Dengan demikian bahwa F-hitung > F-tabel dengan tingkat signifikan $0,000<0,05 \quad(\mathrm{p}<0,05)$. Adanya kenaikan brand image, persepsi harga, dan kualitas layanan secara bersama-sama maka akan di ikuti perubahan minat beli ulang secara signifikan.

Minat beli ulang konsumen pada Lazada di pengaruhi brand image, persepsi harga, dan kualitas layanan sebesar 56,8\% sedangkan sisanya sebesar 43,2\% dipengaruhi faktor lain. Brand Image menunjukkan variabel ini berpengaruh positif signifikan terhadap minat beli ulang pada lazada. Maka semakin tinggi brand image maka semakin tinggi pula minat beli ulang yang dirasakan oleh pengguna. Sehingga berdasarkan hasil penelitian tersebut 
diharapkan Lazada mampu mempertahankan dan meningkatkan brand image melalui indikator yang digunakan untuk mengukur brand image yaitu:

1) Citra pembuat yaitu sekumpulan asosiasi yang membuat dipresepsikan konsumen terhadap perusahaan yang membuat suatu produk atau jasa.

2) Citra pemakai yaitu sekumpulan asosiasi yang dipresepsikan konsumen terhadap pemakai yang menggunakan barang atau jasa.

3) Citra produk yaitu sekumpulan asosiasi yang dipresepsikan konsumen terhadap suatu produk

Kualitas Layanan berpengaruh positif signifikan terhadap minat beli ulang. Maka dapat disimpulkan dengan hal ini kualitas layanan akan menimbulkan minat beli ulang. Sehingga kualitas layanan yang dirasakan oleh pengguna akan terus diingat dan terus memperbaiki kualitas layanan agar tidak kehilangan pelangan. Yaitu dengan cara melalui indikator yang digunakan untuk mengukur kualitas layanan yaitu:

1) Bukti langsung (Tangible)

2) Kehandalan (Reliability)

3) DayaTanggap(Responsivenness)

4) Jaminan (Assurance)

5) Perhatian (Empathy)

\section{DAFTAR PUSTAKA}

Arsyanti, N. M., \& Astuti, S. R. T. (2016). Analisis Pengaruh Kualitas Produk, Kualitas Layanan dan Keragaman Produk Terhadap Kepuasan Pelanggan Serta Dampaknya Terhadap Minat Beli Ulang (Studi pada Toko Online Shopastelle, Semarang). Diponegoro Journal of Management, 5(2), 291-301.

Bilgin, Y. (2018). The effect of social media marketing activities on brand awareness, brand image and brand loyalty. Business \& management studies: an international journal, 6(1), 128-148.

Cahyono, T. D. (2016). Analisis Pengaruh Persepsi Kualitas dan Persepsi Nilai Terhadap Kepuasan Konsumen dan Minat Beli Ulang. Jurnal Tambora, 1(3), 11-24

Dharmestha, S. B., \& Handoko, T. H. (2008). Manajemen Pemasaran: Analisa Perilaku Konsumen, edisi pertama, cetakan keempat. BPFE, Yogyakarta.

Fatmawati, N., \& Soliha, E. (2017). Kualitas Produk, Citra Merek Dan Persepsi Harga Terhadap Proses Keputusan Pembelian Konsumen Sepeda Motor Matic "Honda". Jurnal Manajemen Teori dan Terapan, 10(1), 1-20.

Ferdinand, Augusty. (2006). Metode pene;itian manajemen. Pedoman penelitian untuk penulisan skripsi, tesis, dan disertasi Ilmu Manajemen, Badan Peneliti Universitas Diponegoro

Ghozali, I. (2011). Aplikasi Analisis Multivariate dengan Program IBM SPSS 19. Semarang: Badan Peneliti Universitas Diponegoro. Edisi Kelima

Gofur, A. (2019). Pengaruh kualitas pelayanan dan harga terhadap kepuasan pelanggan. Jurnal Riset Manajemen Dan Bisnis (JRMB) Fakultas Ekonomi UNIAT, 4(1), 37-44.

Hadi, A. S. (2018). The effect of dependency on repurchase intention and technostress. Jurnal Maksipreneur: Manajemen, Koperasi, dan Entrepreneurship, 8(1), $1-14$. 
Hana, K. F. (2019). Minat Beli Online Generasi Milenial: Pengaruh Kepercayaan dan Kualitas Layanan. Jurnal Bisnis dan Manajemen Islam, 7(2), 206.

Hidayah, S. A., \& Apriliani, R. A. E. (2019). Analisis Pengaruh Brand Image, Harga, Kualitas Produk, Dan Daya Tarik Promosi Terhadap Minat Beli Ulang Konsumen Batik Pekalongan (Studi Pada Pasar Grosir Setono Batik Pekalongan). Journal of Economic, Business and Engineering (JEBE), 1(1), 24-31.

Kotler, P., Armstrong, G., Ang, S. H., Leong, S. M., Tan, C. T., \& Ho-Ming, O. (2012). Principles of marketing: an Asian perspective. Pearson/Prentice-Hall.

Lupiyoadi, Rambat. (2013). Manajemen Pemasaran Jasa, Jakarta: Salemba Empat.

Nisa, A. S. (2018). Analisis Pengaruh Harga Kepercayaan Dan Kualitas Pelayanan Terhadap Minat Beli Ulang Dalam Berbelanja Online Di Instagram (Studi Empiris Pada Mahasiswa Universitas Muhammadiyah Surakarta) (Skripsi, Universitas Muhammadiyah Surakarta).

Ramadhan, A. G., \& Santosa, S. B. (2017). Analisis pengaruh kualitas produk, kualitas pelayanan, dan citra merek terhadap minat beli ulang pada sepatu nike running di semarang melalui kepuasan pelanggan sebagai variabel intervening. Diponegoro Journal of Management, 6(1), 59-70.

Rangkuti, F. (2009). Mengukur Efektivitas Program Promosi \& Analisis Kasus Menggunakan SPSS. PT Gramedia Pustaka Utama.

Saidani, B., Lusiana, L. M., \& Aditya, S. (2019). Analisis pengaruh kualitas website dan kepercayaan terhadap kepuasan pelanggan dalam membentuk minat pembelian ulang pada pelanggan shopee. JRMSI-Jurnal Riset Manajemen Sains Indonesia, 10(2), 425444.

Sugiyono. (2013). Metode penelitian Kualitatif dan Kuantitatif. Bandung: Alfabeta.

Tjiptono, Fandy. (2008). Strategi Pemasaran. Edisi 3. ANDI: Yogyakarta.

Winahyu, D. J., \& Soesanto, H. (2012). Analisis Pengaruh Persepsi Harga, Kualitas Produk dan Daya Tarik Iklan terhadap Minat Beli Air Minum Axogy (Studi Kasus pada Pengguna Air Minum Kota Magelang Jawa Tengah) (Doctoral dissertation, Fakultas Ekonomika dan Bisnis).

Wulandari, R. D., \& Iskandar, D. A. (2018). Pengaruh citra merek dan kualitas produk terhadap keputusan pembelian pada produk kosmetik. Jurnal Riset Manajemen Dan Bisnis (JRMB) Fakultas Ekonomi UNIAT, 3(1), 11-18.

Zulkarnaen, W., \& Amin, N. N. (2018). Pengaruh Strategi Penetapan Harga Terhadap Kepuasan Konsumen. Jurnal Ilmiah MEA (Manajemen, Ekonomi, \& Akuntansi), 2(1), 106-128. 